\title{
Learning and competences of management students in Brazil: the participation of organizations and university in process of supervised internship
}

\author{
Roberto Rodrigues de Souza Júnior \\ Master science in Administration at Program Pos Graduations in Administração (PPGAdm)/ \\ Federal University of Espirito Santo (UFES) \\ Miguel Carlos Ramos Dumer \\ Doctor candidate in Administration from the Federal University of Espírito Santo (UFES) \\ Master of Science in Accounting from the FUCAPE Business School
}

\section{Alexandre dos Santos Cerqueira}

Doctor candidate in Administration from the Federal University of Espírito Santo (UFES) Master of Science in Administration from the FUCAPE Business School

\section{Mark Miranda de Mendonça}

Master of Science in Accounting from the FUCAPE Business School

Teacher in University Center Projection

\section{Filipe Bressanelli Azevedo}

Master of Science in Accounting from the FUCAPE Business School

Teacher in University Center Projection

\begin{abstract}
The main objective of this study is to describe and analyze the contribution of universities and businesses in the learning and development of professional skills of supervised students in the Administration of the Federal University of Espírito Santo (Brazil). The main approaches that anchor the present study focus on the individual actions that generates learning and consequently the development of competencies. Thus, the concepts of competency learning through social, experiential and educationbased approaches to build competencies and resources mobilization. The present qualitative research approach used the interpretative paradigm. We applied the technique of in-depth interview for the data collection, and for the discussion of the results, we used the qualitative data analysis. As a result, we found the need for a new look at the supervised internship discipline both by the organizations and the University. Additionally, we found the need to create an environment that allows greater interaction between the actors directly involved, providing new tools to follow the discipline with greater control by coordinators and internship process norms. All these results can make possible the integration of content and practice in an effective way.
\end{abstract}

Keywords: Organization Learning; Competences; Supervised Internship.

\section{INTRODUCTION}

In recent years, the supervised internship discipline has been the subject of debates, mainly about its objectives and forms of development. In Brazil, its conception was given by Federal Law No. 6,494, sanctioned on 07/12/1977 (Brazil, 1977) and its regulation was given by Federal Decree No. 87.497 of 08/18/1982 (Brazil, 1982). On September 25, 2008, the Federal 
Government enacted Law no. 11,788 (Brazil, 2008), known as the New Internship Law, which now becomes the new framework that regulates all aspects of the internship discipline in the country's undergraduate courses.

Federal Law No. 11,788 (Brazil, 2008), in its article 1, defines an internship as "a supervised school education act, developed in the work environment, aimed at preparing for the productive work of students who are attending regular education in institutions of higher education $[. .$.$] ".$

According to the guidelines established in Law 11.788 (Brasil, 2008), decree 3388-R (Espírito Santo, 2013), two categories of the internship: compulsory, which is that previously defined in the course's pedagogical program and which has a the timetable to be fulfilled and the noncompulsory, which is the one that the student performs as an optional complement to what is learned in the classroom and the intern must fulfill an established workload. At this internship, there is a pecuniary counterpart called the scholarship grant, aimed at financially subsidizing the student with expenses during his period of study.

That being said, the extracurricular supervised placement enters the picture as a proper and important space for both students and organizations. For organizations, it can be used as a retention channel for new talent that can add new insights and ideas to the organization. For individuals, it can be a source of learning of professional competences from the possibility of joining the theory studied in educational institutions with the practice carried out in the organizational context (Roesch, 1995).

In addition, the compulsory subject of supervised internship is connected with the extracurricular actions that the student develops in the organizations, with that, this discipline is given by a tutor, whose function is to allow these trainee students to interpret and reflect on the contents of the classroom and its connection with the practices developed in the organizational environment of the extracurricular internship, since such practices are fundamental requirements for qualification and professional training of the student.

In this context, the accomplishment of this study has as justification to contribute with this discussion in the scope of the Brazilian Universities. Since law regulates the practice of the supervised internship, thus, discussing, reflecting and seeking proposals that enable the practice of internships in administration at a high level of competence learning by students' parts, is relevant to the current context. The purpose of this study is to describe and analyze the participation of organizations and the University in the process of learning and developing professional skills of supervised students of the UFES Administration course.

\section{THEORETICAL REFERENCE}

It is not today that the antagonisms involving the topic of organizational learning have been discussed in the academic and organizational environments themselves. When they conducted a survey on this topic, Easteby-Smith, Crossan, and Nicolini (2000) found that the existence of the perception of a dormancy in the following debates: organizational learning vs. learning organizations, single-loop vs. double- learning x unlearning, learning for cognitive $\mathrm{x}$ behavioral change and the classic discussion between individual and organizational learning.

On the other hand, these same authors argue that it is not possible to state that these discussions were extinguished since they have provided and provide until today a theoretical background that enables the fomentation of new discussions and, above all, the creation of 
fertile ground for the emergence of new concepts. Brandi and Elkjaer (2011), when revisiting the literature, also confirm that, currently, the focus of studies on organizational learning involves the themes: process, content, concept and the relationship between individual and organization.

Therefore, the present study is delimited in the approach of learning from the action of the individuals for the development of competences. Freitas and Brandão (2006) affirm that the learning is a process that allows the individual to acquire competencies. Fleury and Fleury (2001) reinforce that the notion of competences is associated with several verbs, among them "learning to learn". In this line, several authors use the learning approach articulated with the process of competency development, such as Ruas (2001), Antonello (2003), Dutra (2004), Bitencourt (2004).

From this perspective, the development of competences can be facilitated and understood from several learning perspectives. In social learning, the emphasis is on the acquisition of knowledge through experience and research, as well as the development of identities and socialization through the adaptive capacity of individuals. Thus, through the occurrence of tensions and ruptures, it is possible to understand how the processes of this learning occur (Brandi and Elkjaer, 2011).

In the perspective of Kolb's (1984) classic study of experiential learning, it can be defined as a process by which knowledge is generated through the transformation of experience and that knowledge is indeed a process of transformation that must be constantly created and recreated. Kolb (1984: 38) states that "learning transforms experience in both its objective and subjective forms. Finally, to understand learning, we must understand the nature of knowledge, and vice versa."

Also, on the approaches that focus on learning in action for skills development, the informal learning perspective also contributes to this process. Informal learning can occur in educational institutions, but they do not. It is the type of learning that occurs when individuals perform activities in or outside organizational settings. When it is not intentional, learning is called incidental, that is, it occurs as a kind of side effect of activity (Marsick; Watkins, 1990).

The perspective of informal learning is quite broad because it refers to the idea of learning that occurs both in the individual and in the social field. According to Cheetham and Chivers (2001), the informal learning developed by workers during professional practice makes it possible to acquire skills and improve practices through experience. Thus, often the learning experiences that occur in the organizational environment occur in an unplanned way and are originated from simple needs, such as doubts about the way the activities are executed or about the work itself (Coelho Júnior and Mourão, 2011). As a result, these same authors affirm that the fact that they are not planned, this process has no cost to the organization, unlike the development and education processes that must be planned and there are budgets of their own.

Given this, once the individual mobilizes all these resources, i.e., the processes of social, experiential, informal and incidental learning, there is, therefore, the learning of skills, since the fact of just learning also does not condition to the full development of individual knowledge (LeBoterf, 2006). Perrenoud (1999, p.23) defines that "building a competence means learning to identify and find relevant knowledge". Zarifian (2011) concluded that the practical understanding emphasizes learning that is fundamental to competence. 
Therefore, the development of the supervised internship is only possible with the research activity and with the effective participation between teacher and student, where the teacher has a fundamental role, since it is he who must cultivate in the student the capacity of analysis and problematization of the actions and the practices, confronting them with theoretical references, with experience from other perspectives and from other social actors. In this sense, the learning and the development of competencies are emphasized to legitimize the results of the practices of an internship, which has the educational objective of the student's professional training (Lima and Pimenta, 2005).

According to Aktouf (1996), teachers should integrate, among other aspects, adherence to a participatory, clear and collaborative teaching environment to ensure that students are understanding the depth of the subject and also integrate the experienced practice as the foundation of training. In the University / Company context, the internship also lacks this integration and, in this sense, has another role, which is to establish the importance of the internship beyond the economic-social idea. This integration is the bridge to the understanding and improvement of the concepts acquired in the training course, providing the student with an understanding of the value of work and the social idea of profitability, which is the factor that drives economic activities (Gluck, 1979).

\section{METHODOLOGY}

In this qualitative study, regarding the objective, it can be classified as descriptive. In this type of research, one or more phenomena are observed, described, analyzed and interpreted (Gil, 2002). This type of research is appropriate to the phenomenon studied, because it was desired to study the relationship between learning and the development of competences under the point of the managers of the trainees in their work environment (organizations) and of the professors of Federal University of Espírito Santo (Brazil), who are the research subjects of this study. For Cervo and Bervian (2004), the descriptive research observes, registers, analyzes and correlates facts or phenomena with the purpose of providing more information on the subject.

Therefore, the approach adopted for research is qualitative. According to Richardson (1999), this approach serves to describe a phenomenon deeply. In it, the researcher does not intend to enumerate or measure, from variables, the events studied. It starts with broad questions that are being defined as the study progresses. Researchers who adopt this approach argue that a phenomenon can be better understood in the context in which it occurs and of which it is a part. In this context, qualitative research also carries the characteristic of creativity, which conditions the researcher to become involved in the studied environment and this space becomes propitious for constructing interpretations based on empirical findings (Denzin and Lincoln, 1998)

\section{Data collection}

Richardson (1999) states that through the technique of unstructured or "in-depth" interviewing, as is also known, it is possible to obtain a very rich material for analysis, which allows understanding the phenomena using unstructured interviews involving the research subjects. Thus, the interviews were conducted based on two scripts with two actors involved in the internship process. Thus, seven interviews with representatives of Federal University of Espírito Santo were carried out (Table 1). In the organizations' perspective, six public and private organizations of different segments and structures were selected (Table 2). With this, the IU and IO acronym were used to represent the interviewees of the University and the organizations respectively. 


\begin{tabular}{lll}
\hline Identification & Education / Degree & $\begin{array}{l}\text { Teaching } \\
\text { period }\end{array}$ \\
\hline IU1 & Doctorate in Production Engineering & 7 years \\
IU 2 & Doctorate in Economics & 4 years \\
IU 3 & Doctorate in Production Engineering & 12 years \\
IU 4 & Doctorate in Energy Planning & 1 year \\
IU 5 & Doctorate in Administration & 15 years \\
IU 6 & Doctorate in Production Engineering & 4 years \\
IU 7 & Doctorate in Administration & 1 year \\
\hline
\end{tabular}

Table 1: Subjects Profile on the University: Source: Prepared by the authors (2018)

\begin{tabular}{lll}
\hline Identification & Function/job & Sector \\
\hline IO 1 & Project Coordinator & Public \\
IO 2 & Investment Advisor & Private \\
IO 3 & Special Advisor & Public \\
IO 4 & HR Analyst & Private \\
IO 5 & Project Coordinator & Private \\
IO 6 & Psychologist & Public \\
\hline
\end{tabular}

Table 2: Subjects Profile on Organizations: Source: Prepared by the authors (2018)

\section{RESULTS DISCUSSION}

After the floating and deep readings of the transcripts, the data were codified and categorized, being these processes carried out in the light of that proposed by Gibbs (2009). Thus, following the same author's perspective, coding represents a way of indexing a set of ideas and thematic categorization, it brings the notion of separation by themes into a more analytical and detailed level.

After this, in table 3 a schematization is presented, where, at first, the codification and categorization were carried out in the view of the university representatives. After this process, the codes and categories are used to subsidize the interpretation of the qualitative data when linking the findings of the research with the theoretical reference.

\begin{tabular}{ll}
\hline Internship & $\begin{array}{l}\text { Knowledge application } \\
\text { Merge theory with practice }\end{array}$ \\
\hline Contributions & Intermediation between organization / student / university \\
\hline Skills & Managerial competence \\
& Relationship and leadership skills \\
\hline Improvements & $\begin{array}{l}\text { Approximate and effective follow-up by teachers } \\
\text { New tools and methods for monitoring } \\
\end{array}$ \\
& Major Integration Company / University \\
\hline
\end{tabular}

Table 3: Codification and Categorization for UFES Interviewees: Source: Prepared by the authors (2018)

\section{University participation}

The internship code refers to the role that the supervised internship represents for the teachers and counselors of the students. Thus, the IU3 states that "[...] the internship helps a student to make the comparison theory and practice with more assertiveness because there he glimpses what is his profession with what he corroborates or not, and also with what is the reality of this for him [...] ". 
In this context, both the application of knowledge and the ability to unite theory and practice are related to the life cycle of Kolb (1984), which proposes that experiential learning is based on four modes of interaction between the individual and the environment, these modes being characterized by concrete experience, reflexive observation, abstract conceptualization and active experience (figure 1).

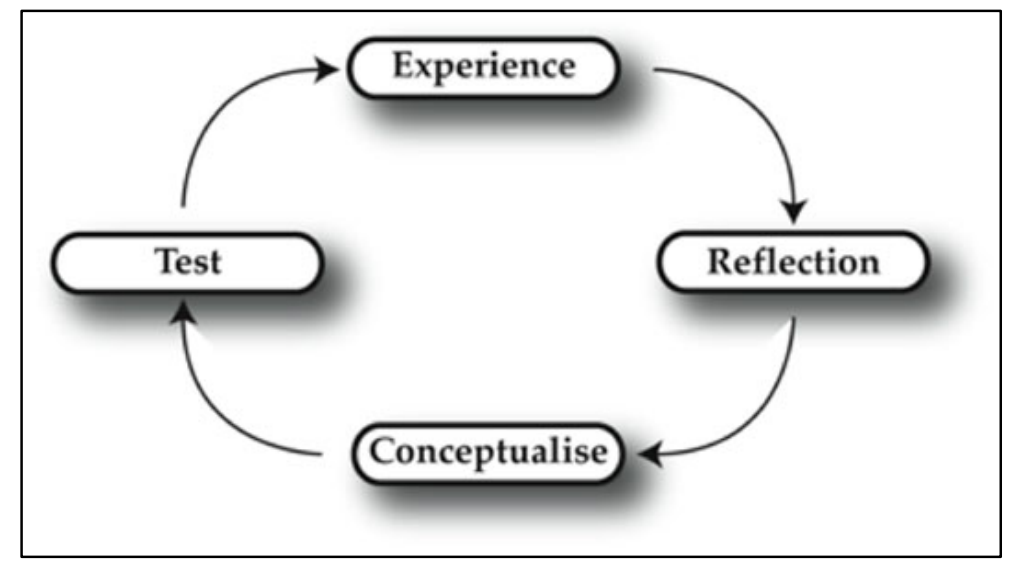

Figure 1: Kolb cicle: Source: (1984)

Still with Kolb (1984) the individual, from his lived experiences, reflects, establishes models of action and experiences in similar situations, thus generating a learning cycle. Also, the supervised internship environment is therefore framed as the locus where the professional character of the student is generated, constructed, perfected and also where the development of activities experienced in practice generates learning, capacity for reflection, criticism (Buriolla, 2001) and consequently the development of skills.

Regarding the code, the university's contributions to learning students' skills through the internship process, the IU7 states: "I think that the University has a role of intermediation, of serving as this bridge between the student and the market and also of doing this suitability most advantageously for the student through the teacher [...] ". From this perspective, Perrenoud (1999) raised some criticisms of content education focused on the transmission of information. For this author, discussions about changes in the world of work, which gave rise to the idea of a new worker, gave birth to the notion of competence in the area of education, with this, the role of the teacher is fundamental to provoke in students the consciousness that the learning process should make them "heads made", that is, different from the traditional conception of accumulation of knowledge that advocates a "full head" perspective.

As for the code of competences, the teachers believe that in addition to the relationship skills, technical and analytical dimension that is also mentioned by the interviewees of the organizations, the student develops more comprehensive competencies, such as leadership and managerial competence. Therefore, the IU5 affirms the following competencies that are developed by these students in internship processes:

"[...] reflective act that is to reflect on practice/theory, analytical ability let's say so; this relationship issue also, the competence of the "know to be" because when you get into the organizational world you will have to deal with people, and I think that is the most important ability and technical issues also that he will get a practice, the "know-how" that is very important to him ".

Lopes (2006) argues that managerial competence can not only be learned in the classroom, because the dynamics of the business environment enables good administrative practice and 
improves the specific learning of a given organization, its products, processes and structures , its markets, its technologies, finally, enables the individual the ability to dominate the subsystems of the organization and have the capacity to analyze the exact moment for decision making and its effects. These arguments justify the learning of competences by trainees in an organizational environment.

In this last question, the teachers were asked which improvements could be implemented in the internship process, the answers pointed to the execution of actions for the close and effective monitoring of teachers, new tools and methods for follow-up and greater integration between company and University. In this sense the IU6 states:

"It would be necessary to follow-up, a follow-up so to say, more present and more forceful, both by the guiding teacher and both by the coordinator. A portfolio of companies that are receptive to UFES students should be created because it has a differentiated profile and prospects for the market, which should be the competence of the University. Avoid this repetition of reports that we see every six months where one student does and passes to the other and hence we do not have absolute control over what is produced he does not even go to the company and ends up doing plagiarism of reports from the friend [...] ".

In this context, it is possible to relate to what Cheetham and Chivers (1996) defend, that is, the effective execution of activities, also includes the need to master discrete skills (values and ethical competence), however, the focus still remains on articulation of all these essential elements (skills and knowledge) to achieve the results. Thus, the improvements in the internship process are due to the need for students to be committed to the objectives, the University's need to invest in tools to monitor students' activities with organizations.

\section{The participation of organizations}

In the second internship, codification and categorization were carried out following the same distribution scheme, observing now in the view of the representatives of the organizations, as shown in table 4.

\begin{tabular}{cl}
\hline \multicolumn{1}{c}{ Profile } & $\begin{array}{l}\text { Behavioral Aspects } \\
\text { Technical concepts }\end{array}$ \\
\hline Development & $\begin{array}{l}\text { Meetings, Lectures, and Conversation Wheels } \\
\text { Qualifying Programs } \\
\text { Learning and Development with a }\end{array}$ \\
\hline Competence & $\begin{array}{l}\text { Social Competence } \\
\text { Analytical Skills }\end{array}$ \\
& Technical-professional skills \\
\hline Getting the & $\begin{array}{l}\text { Performance } \\
\text { job }\end{array}$ \\
& $\begin{array}{l}\text { Get into learning and making new skills } \\
\text { Achieve consistent results }\end{array}$ \\
\hline
\end{tabular}

Table 4: Codification and categorization in the vision of representatives of organizations: Source: Prepared by the authors (2018)

As for the code profile of trainee that the organizations use for selection, it was observed that the organizations seek trainees adapted to their objectives, in this sense I01 states that the profile used for selection is: "preferably with more than one competency: focus on results quality of delivery, Interpersonal skills, adaptability, and flexibility. In addition to specific technical competencies for each job [...] ". There are also cases in which the selected profile is 
not defined based on interview processes or subjective analysis of the candidate regarding behavioral, psychological and performance issues, are the cases evidenced by I03, which states: "We use only the socioeconomic profile, because the objective of the program is exactly to end the appointment of trainees to the organs [...] ".

As for the actions of organizations to train and develop trainees, i.e., development code, respondents mostly related training and development only with the practice of internship activities. Therefore, there is a lack of initiatives in this regard on the part of the organizations, except the organization of I01 that said: "We have a program focused on trainees called 'Transform', where trainees, according to the time they have here, receive a route of training to be fulfilled, this route is called 'Route to transform' [...] ".

About the skills that students can acquire in an internship process, the respondents were predominantly responsible for technical-professional and relationship skills. The IO1 also mentions: "Competence of Analysis and solution of problems, it is clear that the trainees are here to learn, but they can give opinions ...". It can be seen that both the role of the administration trainee as well as the profile that the organizations seek have common characteristics about the competency learning issues, that is, the student starts from classroom theory to practice within organizations, and through a process of learning and experience, he will acquire skills.

In this sense, it is possible to identify traces of McClelland's (1973) studies in which he considers intelligence as a propelling factor for the achievement of competence and the studies of Kolb (1984) in which he affirms that experiential learning is a process by which knowledge is generated through of the transformation of experience and that knowledge is indeed a process of transformation that must be constantly created and recreated. Addressing what it takes for a trainee to achieve effectiveness, performance issues and consistent presentation of results in this regard, IO3 states that "the professional effectiveness of a trainee follows these criteria."

The interest in learning and developing new skills was also pointed out as one of the trait characteristics of trainees. In this sense, it is interesting to draw a parallel with Flores and Flores (2009, apud Sendin, 2002) in which they affirm that one of the objectives of the administration course is to awaken entrepreneurship in the student, and at this point the internship can enable the student to play this entrepreneurial spirit, since the student can: rehearse, research, without the commitment of results. That is, in addition to the opportunity that the student trainee has to become effective as an employee of the company he can develop his entrepreneurial capacity and consequently find out if his vocation is to be a real businessman.

\section{CONCLUSIONS}

In analyzing the role of the trainee legislation in trainee training through this study, it was possible to verify in organizations that there is no formal enforcement requirement from the government, in some cases, in fact, follow the legislation and make it possible to student an appropriate internship environment and even enhance the internship process with internal rules. On the slope of the university also occurs the same, that is, the collection for the performance of the role of the internship must start with the own teachers who accompany these students. 
Regarding the performance of the role of the traineeship in the study, it was possible to verify several points of view, and it also points to the need to obtain new answers through new studies. One example would be the need for better monitoring of supervised training reports on the part of the teachers, so that the students can actually do an immersion in the organizational world and not only have the supervised internship as a compulsory subject; the need for new methods for the development of the discipline; the teachers present to the students from the first disciplines through activities, forms and situations in which this student can already experience and analyze the connection theory and practice.

In terms of organizations, to wake up about the real possibility of hiring good professionals who already work in these companies and for this to have the university as a support agent providing these professionals; the creation of a database for companies to consult the profiles of the students that are available to practice based mainly on academic performance so that it can also organize and centralize the offer and dissemination of traineeships and as regards the contribution of organizations for learning is that these organizations can provide a transformational internship environment in which students can effectively experiment, create, learn, and principally apply the theories learned in the classroom.

In conclusion, it is possible to observe through this study that both the supervised internship of the Federal University of Espírito Santo in administration course as well as the participation of the companies in this process have points to be improved, but it should be noted that the internship is already playing its role with positive results on both sides when you want to have that result. Because the participation and dedication of all actors in the process are fundamental to the fact that the expected result should happen, a new look is required for supervised internship and internship in the organizational environment and for this to happen the actors in this process must also play its role always following principles, concepts and especially legislation.

\section{References}

AKTOUF, O. A administração entre a tradição e a renovação. São Paulo: Atlas, 1996.

ANTONELLO, C. S.; RUAS, R. Repensando os Referenciais Analíticos em Aprendizagem Organizacional. Revista Administração Contemporânea-RAC, v. 7, n. 3, pp. 203-212, 2003. Disponível em: http://www.scielo.br/scielo.php?script=sci arttext\&pid=S1415-65552003000300011. Acesso em: 07 Set. 2018.

BITENCOURT, C. A gestão de competências gerenciais e a contribuição da aprendizagem organizacional-a experiência de três empresas australianas. Revista de Administração Mackenzie-RAM, v. 3, n. 1, 2004. Disponível em: <http://www.scielo.br/pdf/rae/v44n1/v44n1a04.pdf>. Acesso em: Acesso em: 07 Set. 2018.

BRANDI, U.; ELKJAER, B. Organizational Learning Viewed from a Social Learning Perspective. In: EASTERBYSMITH, M; LYLES, M. A. (Org.). Blackwell handbook of organizational learning and knowledge management. 2nd ed., p. 23-37, 2011

BRASIL. Lei n.ำ 6.494, de 07 de dezembro de 1977. Dispõe sobre os estágios de estudantes de estabelecimento de ensino superior e ensino profissionalizante do $2^{\circ}$ Grau e Supletivo e dá outras providências. Legislação Federal, Brasília, 25 dez. 1977. Disponível em: < http://www2.camara.leg.br/legin/fed/lei/1970-1979/lei-6494-7dezembro-1977-366427-publicacaooriginal-1-pl.html> . Acesso em: 07 Set. 2018.

. Decreto no 87.497, de 18 de agosto de 1982. Regulamenta a Lei no 6.494, de 07 de dezembro de 1977. Legislação Federal, Brasília, 18 ago. 1982. Disponível em: <http://www.planalto.gov.br/CCIVil_03/decreto/D87497.htm>. Acesso em: 07 Set. 2018.

. Lei no. 11.788, de 25 de setembro de 2008. Dispõe sobre o estágio de estudantes e dá outras providências. Legislação Federal, Brasília, 25 set. 2008. Disponível em: http://www.planalto.gov.br/ccivil_03/_ato2007-2010/2008/lei/l11788.htm. Acesso em: 07 Set. 2018.

BURIOLLA, M. A. F. O Estágio supervisionado. 3. Ed., p.13 - São Paulo: Cortez, 2001.

CERVO, A. L.; BERVIAN, P. A. Metodologia Cientifica. 5. ed. São Paulo: Atlas, 2004 
Souza, R. R., Dumer, M. C. R., Cerqueira, A. S., Mendonça, M. M., \& Azevedo, F. B. (2018). Learning and competences of management students in Brazil: the participation of organizations and university in process of supervised internship. Archives of Business Research, 6(9), 105-115.

CHEETHAM, G.; CHIVERS, G. Towards a holistic model of professional competence. Journal of European industrial training, v. 20, n. 5, p. 20-30, 1996. Disponível em: <

https://www.emeraldinsight.com/doi/abs/10.1108/03090599610119692>. Acesso em: 07 Set. 2018.

How professionals learn in practice: an investigation of informal learning amongst people working in professions. Journal of European industrial training, v. 25, n. 5, p. 247-292, 2001. Disponível em: <https://www.emeraldinsight.com/doi/abs/10.1108/03090590110395870>. Acesso em: 07 Set. 2018.

COELHO JUNIOR, F. A.; MOURÃO, L. Suporte à aprendizagem informal no trabalho: uma proposta de articulação conceitual. Revista de Administração Mackenzie, v. 12, n. 6, p. 224, 2011. Disponível em:

<http://www.scielo.br/scielo.php?pid=S1678-69712011000600010\&script=sci abstract\&tlng=pt $>$. Acesso em: 07 Set. 2018.

DENZIN, N. K.; LINCOLN, Y. S. Introduction: Entering the fild of qualitative research. In:

DENZIN, N. K.; LINCOLN, Y. S.; YVONNA, S. (Orgs) The landscape of qualitative research: Theories and issues. Sage Publications, 1998.

DUTRA, J. S. Competências: conceitos e instrumentos para a gestão de pessoas na empresa moderna. São Paulo: Atlas, 2004.

EASTERBY-SMITH, M.; CROSSAN, M.; NICOLINI, D. Organizational learning: debates past, present and future. Journal of Management Studies, v. 37, n. 6, p. 783-796, sep. 2000.

ESPÍRITO SANTO (Estado). Decreto no 3388-R, de 24 de setembro de 2013.

Diário Oficial dos Poderes do Estado, Executivo - Anexo, p. 67. Vitória, 25 set. 2013. Disponível em: < https://goo.gl/GcLPvh>. Acesso em: 07 Set. 2018.

FLEURY, A.; FLEURY, M. T. L. Construindo o conceito de competência. Revista de Administração Contemporânea. São Paulo, Edição Especial, p. 183-196, 2001.

FLORES, L. C. C; FLORES, R. O. M. S. Estágio curricular do Curso de Administração do Centro de Ciências Sociais Aplicadas - elemento de integração - Empresa Universidade. Apresentado no VII Colóquio Internacional Sobre Gestão Universitária da América do Sul. Mar del Plata, 2009. Disponível em: < https://goo.gl/BjRAAV>. Acesso em: 07 Set. 2018.

FREITAS, I. A.; BRANDÃO, H.P. Treinamento, Desenvolvimento e Educação em Organização e Trabalho. In: BORGES-ANDRADE, J. E.; ABBAD, G. S.; MOURÃO, L. Treinamento, Desenvolvimento e Educação em Organizações e Trabalho: fundamentos para a gestão de pessoas. Porto Alegre: Artmed, 2006.

GIBBS, G. Análise de dados qualitativos. In: FLICK, U. Coleção pesquisa qualitativa. Artmed, 2009

GIL, A. C. Como elaborar projetos de pesquisa. 4. ed. São Paulo: Atlas, 2002.

GODOY, A. S.; ANTONELLO, C. S.; BIDO, D. S.; SILVA, D. 0 desenvolvimento das competências de alunos formandos do curso de Administração: um estudo de modelagem de equações estruturais. Revista de AdministraçãoRAUSP, São Paulo, v. 44, n. 3, p. 265-278, jul./set. 2009. Disponível em: <http://www.redalyc.org/articulo.oa?id=223417462007>. Acesso em: 07 Set. 2018.

GLUCK, I. Escola/Empresa - A qualificação pelo estágio. Ministério da Educação e Cultura, Departamento de Assuntos Universitários, Publicação do DAU em convênio com o Instituto Euvaldo Lodi/PR, 1979.

KOLB, D. Experiential learning: experience as the source of learning and development.

Englewood Cliffs, New Jersey: Prentice Hall, 1984. 38 p.

LE BOTERF. Avaliar a competência de um profissional: três dimensões a explorar. Reflexão RH, v. 1, n. 1, p. 60-3, 2006. Disponível em: < http://www.guyleboterf-

conseil.com/Article\%20evaluation\%20version\%20directe\%20Pessoal.pdf>. Acesso em: 07 Set. 2018.

LIMA, M. S. L.; PIMENTA, S. G. Estágio e docência: diferentes concepções. Revista Poíesis - Volume 3, Números 3 e 4, pp. 5-24, 2005.

LOPES, P. C. A formação do administrador no ensino de graduação: uma reflexão. Ciências Sociais e Humanas, Londrina, v. 27, n.2, p. 187-201, jul./dez. 2006. Disponível em:

<http://www.uel.br/revistas/uel/index.php/seminasoc/article/view/3749/3009>. Acesso em: 07 Set. 2018.

MARSICK, V. J.; WATKINS, K. E. Informal and incidental learning in the Workplace, Routledge, London. 1990.

MCCLELLAND, D. Testing for Competence Rather Than for Intelligence. American Psychologist, January, 1973. 
PERRENOUD, P. Construir as competências desde a escola. Porto Alegre: Artes Médicas Sul, 1999.

RICHARDSON, R. J. Pesquisa social: Métodos e Técnicas. São Paulo: Atlas, 1999.

ROESCH, S. M. A. Projetos de estágio dos cursos de administração: Guia para pesquisas, projetos, estágios e trabalho de conclusão de curso. São Paulo: Atlas, 1995.

RUAS, R. Desenvolvimento de competências gerenciais e contribuição da aprendizagem organizacional. In: FLEURY, M. T. L.; OLIVEIRA JR, M. M. Gestão estratégica do conhecimento: integrando aprendizagem, conhecimento e competências. São Paulo: Atlas, p. 242-269, 2001

ZARIFIAN, P. Objetivo competência: por uma nova lógica. Tradução Maria Helena C. V. Trylinski. - 1. Ed. - 4. Reimpr. - São Paulo: Atlas, 2011. 